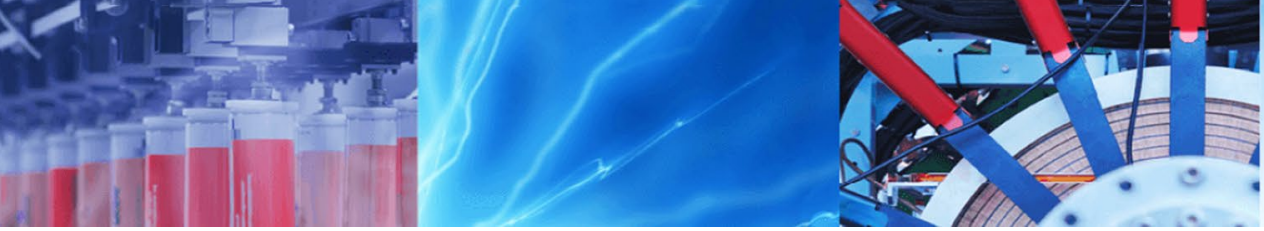

Research Article

\title{
Evaluating crude whey for bioethanol production using non-Saccharomyces yeast, Kluyveromyces marxianus
}

\author{
Asmamaw Tesfaw ${ }^{1}$ [D $\cdot$ Ebru Toksoy Oner ${ }^{2} \cdot$ Fassil Assefa $^{3}$
}

Received: 6 September 2020 / Accepted: 21 December 2020 / Published online: 8 January 2021

(C) The Author(s) 2021 OPEN

\begin{abstract}
Ethanol production from non-food substrate is strongly recommended to avoid competition with food production. Whey, which is rich in nutrients, is one of the non-food substrate for ethanol production by Kluyveromyces spp. The purpose of this study was to optimize ethanol from different crude (non-deproteinized, non-pH adjusted, and non-diluted) whey using K. marxianus ETP87 which was isolated from traditional yoghurt. The sterilized and non-sterilized whey were employed for $K$. marxianus ETP87 substrate to evaluate the yeast competition potential with lactic acid and other microflora in whey. The effect of $\mathrm{pH}$ and temperature on ethanol productivity from whey was also investigated. Peptone, yeast extract, ammonium sulfate $\left(\left(\mathrm{NH}_{4}\right)_{2} \mathrm{SO}_{4}\right)$, and urea were supplemented to whey in order to investigate the requirement of additional nutrient for ethanol optimization. The ethanol obtained from non-sterilized whey was slightly and statistically lower than sterilized whey. The whey storage at $4{ }^{\circ} \mathrm{C}$ didn't guarantee the constant lactose presence at longer preservation time. Significantly high amount of ethanol was attained from whey without pH adjustment (3.9) even if it was lower than $\mathrm{pH}$ controlled (5.0) whey. The thermophilic yeast, $K$. marxianus ETP87, yielded high ethanol between 30 and $35^{\circ} \mathrm{C}$, and the yeast was able to produce high ethanol until $45^{\circ} \mathrm{C}$, and significantly lower ethanol was recorded at $50^{\circ} \mathrm{C}$. The ammonium sulfate and peptone enhanced ethanol productivity, whereas yeast extract and urea depressed the yeast ethanol fermentation capability. The K. marxianus ETP87, the yeast isolated from traditional yoghurt, is capable of producing ethanol from non-sterilized and non-deproteinized substrates.
\end{abstract}

Keywords Bioethanol $\cdot$ Whey $\cdot$ Kluyveromyces marxianus $\cdot$ Lactose $\cdot$ High-temperature ethanol

\section{Introduction}

Cheese whey is the liquid remaining after the precipitation and removal of milk casein during cheese-making. In 2015, 180 million tons of milk whey was generated globally [1], increasing at a rate of $3 \%$ per year [2]. More than half (50\%) of the whey produced worldwide is disposed to rivers, lakes, and other water bodies which represents a significant loss of resource and serious pollution problems [3, 4] since it contains high chemical oxygen demand $(50-80 \mathrm{~g}$ $\left.\mathrm{COD} \mathrm{L}^{-1}\right)$ and high biological oxygen demand (BOD, due to the occurrence of lactose and hardly biodegradable proteins) [5]. Cheese whey can be 100 times more polluting than domestic sewage [6]. Consequently, treatment of whey seems to be a major problem for medium and small-scale cheese-making plants.

Cheese whey has been used for production of ethanol since it contains lactose and other nutrients required for microbial growth [7]. It contains about $7 \%$ solids comprising of $10-12 \%$ proteins, lactose $(74 \%)$, minerals (8\%), and fat (3\%) [8]. Thus, exploitation of microorganisms and whey for production of bioethanol and other

$\triangle$ Asmamaw Tesfaw, asmamawtesfaw@dbu.edu.et; asmamawtesfawbelay2004@gmail.com; Ebru Toksoy Oner, ebru.toksoy@marmara.edu.tr; Fassil Assefa, asefafasil2013@gmail.com; fasil.asefa@aau.edu.et |'Department of Biology, Debre Berhan University, P.O. Box 445, Debre Berhan, Ethiopia. ${ }^{2}$ IBSB, Department of Bioengineering, Marmara University, Goztepe Campus, P.O. Box 34722, Istanbul, Turkey. ${ }^{3}$ Department of Microbial Cellular and Molecular Biology, Addis Ababa University, P.O. Box 1176, Addis Ababa, Ethiopia. 
valuable products offers best alternative to tackle pollution problems.

The fermentation of lactose in crude whey is ineffective from an economic view point due to high dilution and low concentrations of ethanol $(25 \mathrm{~g} / \mathrm{L})$ achieved, requiring high energy inputs for distillation [9]. The production cost of ethanol would be economical when the lactose concentration raised to $100 \mathrm{~g} / \mathrm{L}$ [10]. However, this process by itself is energy demanding process. The simple method to elevate the low sugar concentration is supplementation of cheap carbon sources [10].

Ethanol production from whey is mediated mainly by yeasts that are capable of fermenting lactose in whey. Most of Saccharomyces species can't ferment lactose because they lack the $\beta$-galactosidase enzyme system that degrades lactose into glucose and galactose. Nevertheless, most of the Kluyveromyces species are able to ferment lactose to ethanol of which $K$. marxianus and $K$. lactis are extensively studied for this purpose [11]. Generally, Kluyveromyces species has a number of advantages over Saccharomyces species. For example, unlike Saccharomyces, Kluyveromyces can produce ethanol at higher temperature (even at $52^{\circ} \mathrm{C}$ ); Kluyveromyces species is able to ferment a variety of carbon sources (including inulin, xylose, and lactose), which cannot be fermented by Saccharomyces [12].

Kluyveromyces marxianus has useful physiological features for ethanol production. It is a thermotolerant yeast with high growth rate $[12,13]$. It has the capability to ferment different substrates and many strains have already been recognized as GRAS (Generally Recognized As Safe) $[12,14]$. However, it has a Crabtree-negative character, and the fermentative metabolism is linked to the limitation of oxygen and cannot grow under anaerobic conditions. This study was performed to evaluate ethanol production by $K$. marxianus ETP87 from non-sterilized or non-pasteurized, non-deproteinized, and non-diluted crude whey at different conditions.

Ethiopian cattle number is estimated to be $54,000,000$ that contributes $3.68 \%$ of world cattle population, and this makes Ethiopia to rank 5th in the world and 1st in Africa (FAOSTAT 2013); however, the country is less benefiting from the cattle and livestock production. In Ethiopia, there are more than 32 dairy industries with a projected capacity of 20,000 tons of whey [15]. The potential of using the ever-increasing whey waste to produce bioethanol and biomass from yeast and other microbes is all the more important for a dual function of commodity production and environmental protection. Ethiopia started exporting whey and whey products since 2007; however, the foreign currency earned is very low [16]; this can be improved by producing highly valuable products like bioethanol. On the other hand, the Ethiopian bioethanol production for benzene blending is dependent only on molasses, and it needs to look for other cheap substrates for bioethanol production. Cheese whey can be considered as best alternative in this regards since the expansion of the dairy industries is getting attention by the government this days, and hence, the volume of liquid milk is increasing [17]. The aim of this study was to evaluate ethanol production capability of $K$. marxianus ETP87 from crude cheese whey.

\section{Materials and methods}

\subsection{Whey}

The crude whey was obtained from Shola Dairy Farm (Addis Ababa), Tigist Mini Dairy Processing Unit (Debre Berhan), Amanual Dairy (Debre Berhan), and different rural households near Debre Berhan. The $\mathrm{pH}$ of the whey was measured within $2 \mathrm{~h}$ of sampling.

The ethanol content of the whey was measured according to Patricia [18] before it was used for ethanol production.

\subsection{Molasses}

The molasses, which was produced by Wonji Shoa Sugar Factory, was obtained from commercial market at Addis Ababa, Ethiopia. The molasses was boiled for $30 \mathrm{~min}$ and cooled to sediment the insoluble materials, and further sedimentation was carried out by centrifugation at $5000 \times g$ for $10 \mathrm{~min}$. In order to determine total sugar of the supernatant soluble molasses, the molasses was hydrolyzed by $6 \mathrm{M} \mathrm{HCl}$ for $10 \mathrm{~min}$ in water bath, cooled, and neutralized by $6 \mathrm{M} \mathrm{NaOH}$, and then, the sugar was determined by 3, 5-dinitrosalycylic acid (DNS) method [19, 20]. The total and the reducing sugar of the crude molasses were found to be $40.33 \%$ and $9.62 \%$.

\subsection{Yeast}

The bioconversion of lactose present in crude whey into ethanol was performed by the yeast, K. marxianus ETP87, isolated from traditional yoghurt, maintained in culture collection at Addis Ababa University. This yeast was selected since it fermented lactose as efficient as galactose and glucose. The strain was maintained on agar slant composed of lactose $20 \mathrm{~g} / \mathrm{L}$, yeast extract $10 \mathrm{~g} / \mathrm{L}$, peptone $20 \mathrm{~g} / \mathrm{L}$, and agar $20 \mathrm{~g} / \mathrm{L}$. Then $\mathrm{K}$. marxianus ETP87 was activated in LYP (lactose yeast extract peptone) media composed of lactose $20 \mathrm{~g} / \mathrm{L}$, yeast extract $10 \mathrm{~g} / \mathrm{L}$, and peptone $20 \mathrm{~g} / \mathrm{L}$ at $30^{\circ} \mathrm{C}$ for $24 \mathrm{~h}$ when needs arose throughout the investigation and the 24 -h-old yeast with LYP medium 
was added to the whey during the whole study unless explained.

\subsection{Experimental conditions}

The whey was directly used for ethanol production without deproteinizing and defatting, and it was compared with deproteinized by simple heating [2]. However; clear filtrate was obtained by filtering boiled crude whey though muslin cloth and Whatman paper № 1; it was autoclaved at $121^{\circ} \mathrm{C}$ for $15 \mathrm{~min}$. Ethanol production from autoclaved one was compared with un-autoclaved whey to assess the competition of the yeast with lactic acid bacteria.

\subsection{Supplementation of whey with molasses and nitrogen sources}

Effect of molasses fortification on ethanol yield was conducted to optimize ethanol yield on-five-fold diluted molasses where the $\mathrm{pH}$ was adjusted to 5.0. Each medium was separately prepared in $250-\mathrm{mL}$ flasks containing $100 \%$ molasses alone; $25 \%$ whey and $75 \%$ molasses; $50 \%$ whey and $50 \%$ molasses; $75 \%$ whey and $25 \%$ molasses; and $100 \%$ whey to examine the effects of molasses supplementation as carbon source. All combinations and controls were supplemented with yeast extract $(0.1 \%, \mathrm{w} / \mathrm{v})$ and peptone $(0.5 \%, \mathrm{w} / \mathrm{v})$ and inoculated with $5.6 \times 10^{6} \mathrm{~K}$. marxianus ETP87 cells and incubated on a bath shaker (Clifton, England) at $28^{\circ} \mathrm{C}$ and 100 strokes per minutes for $36 \mathrm{~h}$.

In order to analyze effects of nitrogen supplementation, the whey substrate was also supplemented with yeast extract $(0.55 \%)$, peptone $(1 \%)$, and ammonium sulfate $(0.33 \%)$ and inoculated with $5.6 \times 10^{6} \mathrm{~K}$. marxianus ETP87 cells and incubated on a bath shaker (Clifton, England) at $28^{\circ} \mathrm{C}$ and 100 strokes per minutes for $36 \mathrm{~h}$. The ethanol released was determined [18], and the biomass was quantified by viable count methods that correspond to specific dry weight from YPD control medium containing yeast extract $1 \%$, peptone $2 \%$, and lactose $4 \%$.

\subsection{Effect of $\mathrm{pH}$ and temperature}

The effect of whey $\mathrm{pH}(\mathrm{pH}$ 3.9) on ethanol production was evaluated against the control where the medium $\mathrm{pH}$ was adjusted to 5.0 with sodium hydroxide [3], and it was incubated at $30^{\circ} \mathrm{C}$ for $36 \mathrm{~h}$. Likewise, the effect of temperature on the same was evaluated on the medium (adjusted to $\mathrm{pH} 5$ and fortified with peptone) by incubating at 25, 30, $35,40,45$, and $50^{\circ} \mathrm{C}$ for $36 \mathrm{~h}$. The $K$. marxianus ETP87 inoculum size was $5.6 \times 10^{6}$ yeast cells. The number of yeasts was counted by viable count.

\subsection{Ethanolic fermentation}

Whey fermentation was conducted in 250-ml flask containing $100 \mathrm{ml}$ crude whey in which its $\mathrm{pH}$ was 3.9. The media in the flasks were inoculated with $5.6 \times 10^{6} \mathrm{~K}$. marxianus ETP87 seed cultures which was aerobically grown in broth media (lactose, $20 \mathrm{~g} / \mathrm{L}$; peptone, $20 \mathrm{~g} / \mathrm{L}$; and yeast extract, $10 \mathrm{~g} / \mathrm{L}$ ) for $24 \mathrm{~h}$ at $30^{\circ} \mathrm{C}$. The flasks were covered by cotton rolled with aluminum foil. The fermentation was carried at $30^{\circ} \mathrm{C}$ on water bath shaker at $100 \mathrm{rpm}$, and samples were taken for ethanol, reducing sugar, and biomass determinations at different time intervals.

\subsection{Biomass determination}

One $\mathrm{mL}$ of overnight grew yeast that had different $\mathrm{OD}$ readings was transferred to 2-mL Eppendorf tubes and centrifuged at $10,000 \times g$. The yeast cells were washed three times with distilled water. After centrifugation, the biomass in $1 \mathrm{~mL}$ of the yeast was transferred to preweighed aluminum foil (area, $4 \mathrm{~cm} \times 4 \mathrm{~cm}$ ) and dried at $80^{\circ} \mathrm{C}$ until the weight got constant. Dry yeast biomass ( $\mathrm{g} / \mathrm{L}$ ) was determined by standard curve, $Y=3.2748 X-1.1474$ where $Y$ was yeast dry weight $(\mathrm{g} / \mathrm{L})$ and $X$ was optical reading at $600 \mathrm{~nm}$. The direct dry weight measurement was not employed since the precipitated protein during boiling contributed in weight increment.

\subsection{Lactose determination}

The lactose content of whey was determined as reducing sugar using lactose as a standard according to Ariyanti et al. [2]. The whey was boiled to precipitate proteins and filtered with Whatman №1 using vacuum suction in order to prevent precipitate formation during whey-DNS mixture boiling. Lactose instead of glucose was used to formulate the standard curve. A standard curve of lactose was prepared by using $2.3,2.7,3,3.5$, and $4 \mathrm{mg} / \mathrm{L}$. Finally, the lactose content was determined by $Y=1.5368 X-0.0709$ where $Y$ was the lactose concentration $(\mathrm{mg} / \mathrm{L})$ and $X$ was the optical density at $540 \mathrm{~nm}$.

\subsection{Ethanol quantification}

In order to determine the ethanol, the fermentation samples were centrifuged at $14,000 \times \mathrm{g}$ for $5 \mathrm{~min}$. The supernatant was analyzed by gas chromatography (Agilent $6890 \mathrm{~N}$ ) coupled with a mass spectrometer (MS) with headspace autosampler (Agilent 7694E). The GC-MS was equipped with mass selective detector (Agilent 5973 Network) and a polar polyethylene glycol (PEG) phase DB-wax122-7032 capillary column. Helium was used as a carrier gas. The 
flow rate for the column was $1 \mathrm{~mL} / \mathrm{min}$. The column temperature was held at $40{ }^{\circ} \mathrm{C}$ for $4 \mathrm{~min}$ and then raised to $240^{\circ} \mathrm{C}$ at $40^{\circ} \mathrm{C} / \mathrm{min}$; the inlet temperature was $220^{\circ} \mathrm{C}$. The GC was operated with 20:1 split injection of the headspace.

The mass-to-charge ratios $(\mathrm{m} / \mathrm{z})$ for ethanol was in $31-45 \mathrm{~m} / \mathrm{z}$ range with the retention time of $3.36 \mathrm{~min}$ and for furfural 32-95 m/z range with the retention time of $7.64 \mathrm{~min}$. The MS Quadrupole, MS source, and transfer line temperature were $150^{\circ} \mathrm{C}, 230^{\circ} \mathrm{C}$, and $250^{\circ} \mathrm{C}$, respectively. The conditions of the headspace autosampler were $25 \mathrm{~min}$ for the GC cycle time, $10 \mathrm{~min}$ for the vial equilibration time, $0.5 \mathrm{~min}$ for the pressurization time, $1 \mathrm{~min}$ for the injection time, and a constant vial pressure of $14.0 \mathrm{psi}$. The temperatures were set at $110^{\circ} \mathrm{C}$ for the transfer line to the column and at $90^{\circ} \mathrm{C}$ for the loop. The equilibration temperature was $80^{\circ} \mathrm{C}$ for $10 \mathrm{~min}$. Fermentation samples $(200 \mu \mathrm{L})$ were put in 10-mL headspace vials.

\section{Results and discussion}

\subsection{Ethanol production from different whey sources}

In this study, attempt was made to optimize ethanol production from whey using local non-Saccharomyces yeast, K. marxianus ETP87 (Table 1). The $\mathrm{pH}$ of whey was variable from 3.1 to 4.5 which was very acidic; however, the acidity of whey in other studies was in the range of $\mathrm{pH} 4.3$ and $\mathrm{pH}$ 5.0 depending upon the composition of milk, the variety of cheese made, the storage and handling mechanism of the milk, and the cheese-making process employed $[4,8]$.

The lactose content of the whey was between 18.7 and $34.4 \mathrm{~g} / \mathrm{L}$ (Table 1) which was lower than other reports (34.5 to $48.0 \mathrm{~g} / \mathrm{L})[2,21]$. In addition, high lactose continent in whey (50-60 g/L) was also reported by Ozmihci, Kargi [22].

After keeping the whey in refrigerator for 2 weeks, the lactose content of the whey samples was reduced by $6 \%$ in whey from Shola dairy and by $21-25 \%$ in whey from other whey samples which might be due to the consumption of lactose and production of ethanol by lactic acid microflora and natural ethanologenic yeasts, respectively.
The lower reduction of lactose content was attained from whey under industrial scale cheese-making process in Shola Dairy that was free from direct human hand contact, whereas all others involved household cottage-scale processing at Amanual dairy and Tigist dairy. According to [3], lactose content can be low $(19.3 \mathrm{~g} / \mathrm{L})$ depending upon storage room temperature and the load of lactoseconsuming lactic acid bacteria in whey.

The highest ethanol production of $12.49 \mathrm{~g} / \mathrm{L}$ with $88.09 \%$ efficiency was obtained from whey provided by Shola dairy. The ethanol produced by K. marxianus ETP87 from the three dairies was almost twice as much ethanol as from whey collected from households. In rural areas, the milk is stored for at least 3 days (data not shown) to make cheese, and hence, this would promote the growth of lactic acid bacteria and competent yeasts which lower the $\mathrm{pH}$ and produced ethanol (up to $2.3 \mathrm{~g} / \mathrm{L}$ ) in the whey, respectively (Table 1). The Amanual whey also contained small amount of ethanol $(0.6 \mathrm{~g} / \mathrm{L})$. No ethanol was detected in Tigist mini-dairy and Shola dairy within $2 \mathrm{~h}$ after sampling.

Table 1 shows that the yeast dry weight obtained from Tigist (7.67 g/L) and Shola (7.12 g/L) dairies upon $36 \mathrm{~h}$ incubation was significantly higher than the yeast biomass in whey collected from house hold $(5.48 \mathrm{~g} / \mathrm{L}$ ) showing $18 \%$ difference in ethanol production between the industrially processed whey and the household whey. This was slightly lower than the $8.9 \mathrm{~g} / \mathrm{L}$ biomass obtained from whey by K. marxianus MTCC 1288 after $22 \mathrm{~h}$ of incubation [21]. In other studies, the application of fed batch fermentation process using $K$. marxianus at $30{ }^{\circ} \mathrm{C}$ resulted in $13.4 \mathrm{~g} / \mathrm{L}$ dry weight [2] and $4.43 \mathrm{~g} / \mathrm{L}$ biomass [4] indicating process conditions affect ethanol production from whey.

\subsection{Ethanol production from non-sterilized and sterilized whey}

The effect of sterilization of whey for ethanol production is shown in Table 2. Accordingly, the ethanol concentration reduced after the whey was preserved for 4 days and longer in refrigerator under both sterilized and non-sterilized conditions. However, the sterilized whey resulted in

Table 1 Ethanol and biomass produced by K. marxianus ETP87 from different whey incubated at $30^{\circ} \mathrm{C}$ for $36 \mathrm{~h}$

\begin{tabular}{|c|c|c|c|c|c|c|c|c|}
\hline \multirow[t]{2}{*}{ Whey samples } & \multirow[t]{2}{*}{$\mathrm{pH}$} & \multicolumn{2}{|c|}{ Lactose (g/L) } & \multicolumn{3}{|l|}{ Ethanol ( $\mathrm{g} / \mathrm{L})$ by } & \multirow[t]{2}{*}{ Efficiency (\%) } & \multirow[t]{2}{*}{ Biomass (g/L) } \\
\hline & & Sampling & 2 week later & $\begin{array}{l}\text { Microflora on } \\
\text { time of sampling }\end{array}$ & $\begin{array}{l}\text { Microflora } \\
2 \text { weeks in refrig- } \\
\text { erator }\end{array}$ & $\begin{array}{l}\text { Ethanol by } \\
\text { K. marxianus } \\
\text { ETP87 }\end{array}$ & & \\
\hline Tigist dairy & 4.5 & $34.4 \pm 1.3$ & $27.3 \pm 1.1$ & 0 & $1.2 \pm 0.09$ & $11.62 \pm 0.7$ & & \\
\hline Amanual dairy & 3.8 & $28.6 \pm 1.2$ & $21.5 \pm 0.9$ & $0.6 \pm 0.08$ & $1.7 \pm 0.08$ & $10.54 \pm 0.8$ & 72.26 & $6.20 \pm 0.4$ \\
\hline Household & 3.1 & $18.7 \pm 0.8$ & $14.4 \pm 0.7$ & $2.3 \pm 0.1$ & $1.4 \pm 0.07$ & $6.43 \pm 0.5$ & 67.42 & $5.48 \pm 0.4$ \\
\hline Shola dairy & 4.2 & $27.8 \pm 1.2$ & $26.1 \pm 1.1$ & 0 & $0.8 \pm 0.08$ & $12.49 \pm 0.9$ & 88.09 & $7.12 \pm 0.7$ \\
\hline
\end{tabular}


Table 2 Ethanol produced from non-sterilized and sterilized whey

\begin{tabular}{|c|c|c|c|c|}
\hline \multirow{2}{*}{$\begin{array}{l}\text { Refrigerator } \\
\text { days }\end{array}$} & \multicolumn{2}{|c|}{ Non-sterilized whey } & \multicolumn{2}{|c|}{ Sterilized whey } \\
\hline & $\begin{array}{l}\text { Ethanol } \\
\text { pro- } \\
\text { duced }\end{array}$ & $\begin{array}{l}\% \text { of reduc- } \\
\text { tion }\end{array}$ & $\begin{array}{l}\text { Ethanol } \\
\text { pro- } \\
\text { duced }\end{array}$ & $\%$ of reduction \\
\hline 0 & 11.71 & 0 & 11.68 & 0 \\
\hline 1 & 11.46 & 2.13 & 11.69 & +0.09 \\
\hline 2 & 10.34 & 11.7 & 11.48 & 1.71 \\
\hline 3 & 10.97 & 6.3 & 10.77 & 7.79 \\
\hline 4 & 10.01 & 14.51 & 11.12 & 4.79 \\
\hline 5 & 9.22 & 21.26 & 10.56 & 9.59 \\
\hline 6 & 8.61 & 26.47 & 10.21 & 12.59 \\
\hline 7 & 8.18 & 30.15 & 9.63 & 17.55 \\
\hline 8 & 7.54 & 35.61 & 9.44 & 19.18 \\
\hline 14 & 5.67 & 51.58 & 8.37 & 28.34 \\
\hline Average & 9.11 & & 10.36 & \\
\hline
\end{tabular}

higher ethanol yield than non-sterilized whey. This might be due to whey contamination by microflora and the microflora might cause competition with the ethanologenic yeasts during incubation at $30^{\circ} \mathrm{C}$ for lactose and other nutrients. The ethanol reduction percentage was very significant, especially in non-sterilized whey when the whey was preserved for 4 days and longer in refrigerator at $4^{\circ} \mathrm{C}$.

At the 14 th day preservation, $51.58 \%$ and $28.34 \%$ of ethanol produced from non-sterilized and sterilized whey were reduced due to preservation and contamination showing an almost $50 \%$ reduction between sterilized and non-sterilized whey. However, the pattern of reduction was abrupt for the first 4-5 days in the non-sterilized whey compared to the steady decrease from the sterilized whey.
Zoppellari and Bardi [14] recommended that whey has to be stored at $4{ }^{\circ} \mathrm{C}$ for no more than 3 days.

In general, storage condition potentially mattered a lot to control the lactic acid bacteria. As a result, cold storage condition helps to keep the lactose concentration maximum (greater than $4.5 \mathrm{~g} / \mathrm{L}$ ). Therefore, it is advantageous to properly store whey without pasteurization or sterilization before ethanol fermentation in order to reduce the production cost.

The highest ethanol production $(11.7 \mathrm{~g} / \mathrm{L})$ was attained on both crude non-sterilized and non-refrigerated whey by the yeast. Kluyveromyces marxianus was able to ferment the lactose present in untreated crude whey with ethanol concentration of $7.9626 \mathrm{~g} / \mathrm{L}$ in agitated culture [2]. On the other study, $8.64 \mathrm{~g} / \mathrm{L}$ ethanol was attained by $K$. marxianus from non-sterilized crude whey within $16 \mathrm{~h}$ of fermentation in agitated culture [4]. Therefore, it could be possible to produce ethanol from crude and non-sterilized whey using $K$. marxianus and hence the production cost could be reduced.

\subsection{Effect of whey pH}

The effect of untreated whey $(\mathrm{pH} 3.8-4.5)$ and $\mathrm{pH}$-controlled ( $\mathrm{pH}$ 5.0) whey was investigated to evaluate the capability of the yeast to ethanol production from crude whey. Figure 1 illustrates that the $\mathrm{pH}$-controlled whey $\mathrm{pH}$ 5) yielded higher ethanol than whey without $\mathrm{pH}$ control. Accordingly, the increase in ethanol production due to $\mathrm{pH}$ adjustment in Tigist, Amanual, and Shola whey was 13, 16 , and $15 \%$, respectively, which was significantly different from untreated acidic crude whey. The lower ethanol production from untreated whey is due to the effect of lower $\mathrm{pH}$ on sugar utilization rate by yeasts [7]. However,
Fig. 1 Ethanol produced from $\mathrm{pH}$ controlled and crude whey incubated at $30^{\circ} \mathrm{C}$ for $36 \mathrm{~h}$

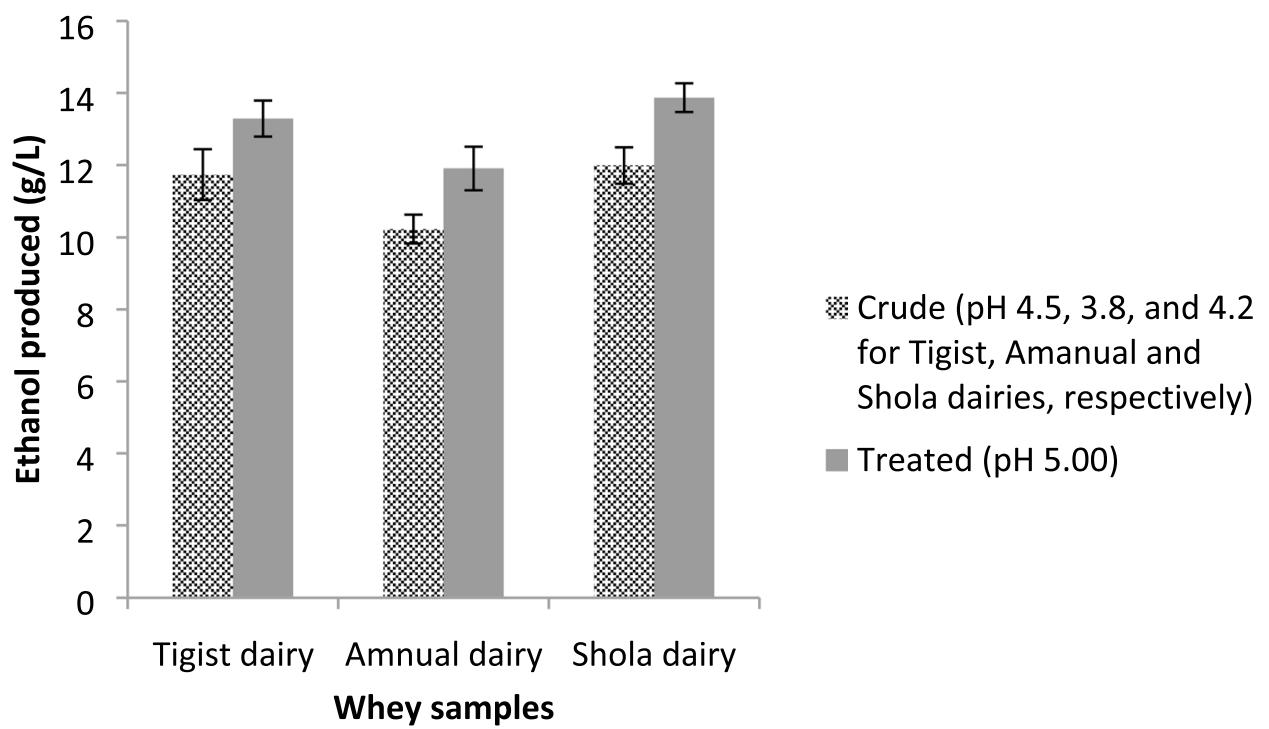

SN Applied Sciences A SPRINGER NATURE journa 
the result suggests that $K$. marxianus ETP87 is capable of producing ethanol from crude whey without controlling its $\mathrm{pH}$.

In this study, ethanol production by K. marxianus (10-12 g/L from untreated whey) was significantly higher than the amount produced ( $7.96 \mathrm{~g} / \mathrm{L}$ ethanol) from non$\mathrm{pH}$-adjusted acidic whey using fed batch mechanisms [2] and $8.64 \mathrm{~g} / \mathrm{L}$ of ethanol produced from fermentation of crude whey without $\mathrm{pH}$ control [4] under $20 \mathrm{~h}$ incubation. The higher concentration in this study may be due to the longer incubation time ( $36 \mathrm{~h}$ ) that could enable the yeast to adapt to the acidity in whey. Likewise, Mohd Azhar et al. [23] concluded that longer incubation period is required to achieve sufficient amount of ethanol production when the $\mathrm{pH}$ is lower (particularly, less than 4.0).

\subsection{Molasses supplementation to whey}

In this study, molasses was added to cheese whey in order to enhance ethanol production. The data showed that cells of $K$. marxianus ETP87 gave higher yield ( $17 \mathrm{~g} / \mathrm{L}, 76 \%$ of the theoretical yield of total sugar) in a combination of $75 \%$ whey and $25 \%$ molasses than the control (100\%) whey and other formulations (Fig. 2). The reduction in the theoretical yield might be due the inability of the yeast to utilize the five carbon compounds available in molasses as reducing sugar. However, the yield was much lower than optimal ethanol $(99 \mathrm{~g} / \mathrm{L})$ production with a combined sugar beet juice $(21 \%)$ and molasses (79\%) medium using K. marxianus KD-15 [10]. The higher ethanol might be related to higher sucrose $(162 \mathrm{~g} / \mathrm{l})$ and lactose $(38 \mathrm{~g} / \mathrm{L})$ with longer incubation period $(80 \mathrm{~h})$, the strain insensitivity to catabolite repression, and the oxygen controlled fermentation conditions (continuous with automated fermenter) [10]. However, in this study, the sugar content were lower than

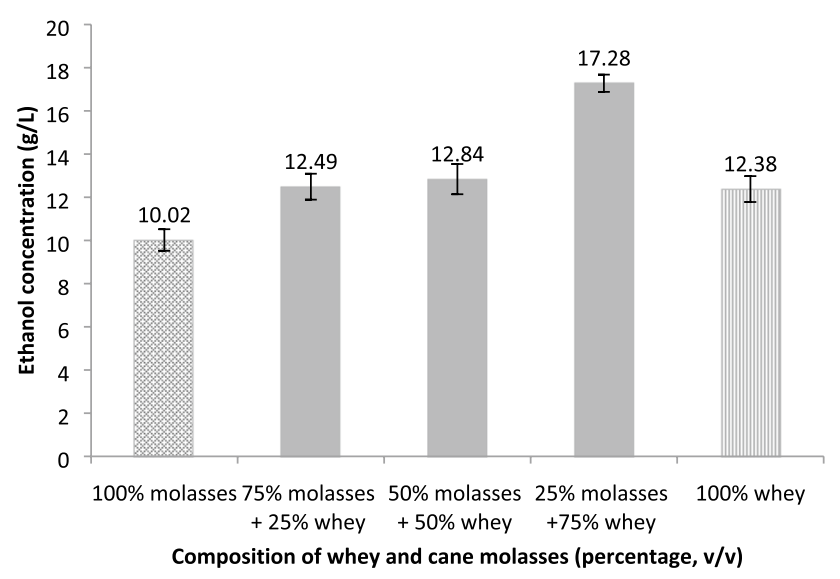

Fig. 2 Ethanol production from whey supplemented with molasses at $30^{\circ} \mathrm{C}$ for $36 \mathrm{~h}$
Oda et al. [10] study and the catabolite insensitivity of $K$. marxianus ETP87 was not studied.

The presence of high glucose concentration in molasses will down-regulate and inhibit enzyme synthesis for assimilation of other sugars present in medium, and then, simple sugars will be consumed before lactose utilization by yeast $[24,25]$. Therefore, the presence of glucose in molasses and whey mixtures might contribute to the lower ethanol production since lag phase is created after the glucose is consumed before ethanol is produced from other sugars. Similarly, Beniwal et al. [25] studied the physiological growth and lactose utilization by $K$. marxianus in mixed sugars (glucose, galactose, and lactose), and they found that the yeast preference was glucose, lactose, and galactose in descending order. When galactose and lactose is present together in fermenting broth of $K$. marxianus, both sugars are simultaneously metabolized, but the rate of lactose utilization is preferentially higher over galactose. Similarly, the yeast utilized galactose and fructose at a similar rate and this might be due to the separate transporter for fructose and galactose [25]. On the other study, fructose exerted repression on the consumption of lactose and two independent growth phases were observed, with a diauxic shift between them [26].

\subsection{Effects of external nutrient additions to whey}

Similarly, the effect of nitrogen additives (peptone, yeast extract, urea, and ammonium sulfate) on ethanol yield from crude whey was assessed, and the results are shown in Fig. 3. The highest ethanol content $(15.9 \mathrm{~g} / \mathrm{L})$ was recorded from supplementation of peptone followed by $15.4 \mathrm{~g} / \mathrm{L}$ ethanol produced from (yeast extract and peptone) and $13.6 \mathrm{~g} / \mathrm{L}$ ethanol produced from whey supplemented with ammonium phosphate. On the contrary,

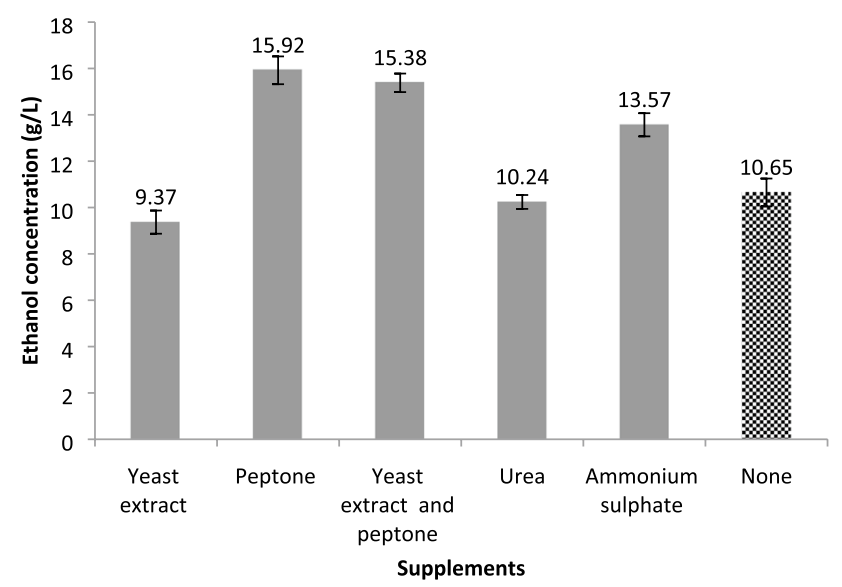

Fig. 3 Nitrogen source supplementation on ethanol productivity incubated at $30^{\circ} \mathrm{C}$ for $36 \mathrm{~h}$ 


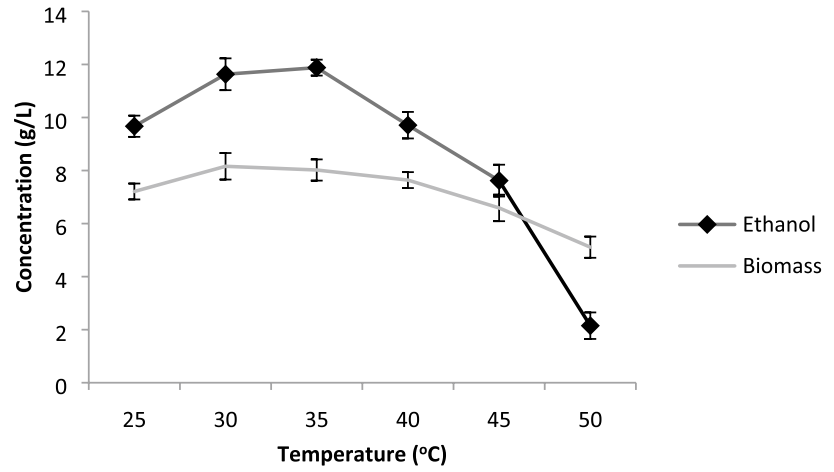

Fig. 4 Ethanol and biomass production from crude whey fortified with peptone incubated at different temperature for $36 \mathrm{~h}$

yeast extract (9.4 g/L) and urea (10.2) supplement showed the lowest ethanol yield that did not show any difference from the control treatment. This indicates that $K$. marxianus ETP87 showed best ethanol yield when whey was fortified with peptone, followed by ammonium sulfate.

However, some studies showed conflicting results in that fortification of growth supplements such as ammonium hydroxide $\left(\mathrm{NH}_{4} \mathrm{OH}, 0.07 \%\right)$ and mono ammonium phosphate $\left(\mathrm{NH}_{4} \mathrm{H}_{2} \mathrm{PO}_{4}, 0.25 \%\right)$ to crude whey resulted in increased ethanol concentrations (by $13 \%$ ) by K. marxianus [8]. On the contrary, Kargi and Ozmıhcı [7] indicated that highest ethanol yield was obtained in whey without any external $\mathrm{N}$ and $\mathrm{P}$ sources indicating that the whey contained sufficient nutrients for bioethanol production by the yeasts. In Murari et al. [27] study, the addition of yeasts extract alone to whey increased the ethanol production but the ethanol concentration was lower when yeast extract and minerals $\left(\left(\mathrm{NH}_{4}\right)_{2} \mathrm{SO}_{4} ; \mathrm{K}_{3} \mathrm{PO}_{4}, \mathrm{MgSO}_{4} ; \mathrm{ZnSO}_{4}\right)$ together was added to whey.

\subsection{Effect of temperature}

The effect of temperature $\left(25-50^{\circ} \mathrm{C}\right)$ on ethanol and biomass production was evaluated, and the result is shown in Fig. 4. The maximum ethanol $(11.86 \mathrm{~g} / \mathrm{L})$ and biomass production $(8.16 \mathrm{~g} / \mathrm{L})$ was obtained under incubation temperatures of $\left(30-35^{\circ} \mathrm{C}\right)$. This was much lower than biomass yield $(17 \mathrm{~g} / \mathrm{L})$ and similar to ethanol yield $(8.1 \mathrm{~g} / \mathrm{L})$ under $30^{\circ} \mathrm{C}$ by $\mathrm{K}$. marxianus [2].

The ethanol production decreased by $35.9 \%$ from 35 to $45^{\circ} \mathrm{C}$ and followed by a sharp decline by $81.9 \%$ at $50{ }^{\circ} \mathrm{C}$ but biomass productivity reduced slowly (by $4.7,18.2$, and $36.3 \%$ ) when the temperature rose from 35 to $50{ }^{\circ} \mathrm{C}$ (Fig. 4). The biomass produced in this study was higher than Sansonetti et al. [28]; however, lower ethanol yield was obtained compared to Sansonetti et al. [28] study, and the lower lactose content might contribute for yield reduction.
Kourkoutas et al. [29] found optimal ethanol (6.5 g/L) at $45{ }^{\circ} \mathrm{C}$ using immobilized $K$. marxianus, but with a significantly lower $(1.8 \mathrm{~g} / \mathrm{L})$ ethanol concentration at $50{ }^{\circ} \mathrm{C}$ that might be related to ethanol loss due to evaporation. However, the boiling point of ethanol is near $78^{\circ} \mathrm{C}$ which is higher than the incubation temperature $\left(50^{\circ} \mathrm{C}\right)$. On the other study, ethanol production sharply declined at $50{ }^{\circ} \mathrm{C}$ due to greater ethanol inhibitory effect of ethanol at higher temperature [30].

Generally, the ability of $K$. marxianus ETP87 to ferment lactose at higher temperature $\left(40^{\circ} \mathrm{C}\right.$ and higher) makes it to be good candidate for industrial application. Among the known yeast species used in fermentation processes, $K$. marxianus is thought to have the best performance for ethanol production at higher temperature [23].

\section{Conclusions}

The data showed keeping the non-sterilized whey in refrigerator at $4{ }^{\circ} \mathrm{C}$ for 5 and more days significantly reduced the ethanol titer when non-sterilized whey was fermented by $K$. marxianus ETP87. This might be due to competition from lactic acid bacteria present in the whey. The fact that ethanol production was equally effective in both the non$\mathrm{pH}$ adjusted and $\mathrm{pH}$ adjusted whey is promising to produce ethanol from whey in which its $\mathrm{pH}$ is not adjusted even if the yeast was able to produce higher ethanol in whey whose $\mathrm{pH}$ was adjusted to 5.0 than non-treated whey. The addition of molasses (25\% molasses and $75 \%$ whey), yeast extract and peptone together, peptone, and ammonium sulfate increased ethanol production by $K$. marxianus ETP87. The ability of $K$. marxianus ETP87 to produce ethanol from whey at $45^{\circ} \mathrm{C}$ confirms that the yeast is thermophilic. This is, therefore, promising to apply the yeast for ethanol production from warm whey before it is dominated by lactic acid bacteria.

\section{Compliance with ethical standards}

Conflict of interest We declare that we do not have conflict of interest.

Open Access This article is licensed under a Creative Commons Attribution 4.0 International License, which permits use, sharing, adaptation, distribution and reproduction in any medium or format, as long as you give appropriate credit to the original author(s) and the source, provide a link to the Creative Commons licence, and indicate if changes were made. The images or other third party material in this article are included in the article's Creative Commons licence, unless indicated otherwise in a credit line to the material. If material is not included in the article's Creative Commons licence and your intended use is not permitted by statutory regulation or exceeds the permitted use, you will need to obtain permission directly from the copyright 
holder. To view a copy of this licence, visit http://creativecommons .org/licenses/by/4.0/.

\section{References}

1. Sebastián-Nicolás JL, González-Olivares LG, Vázquez-Rodríguez GA, Lucho-Constatino Carlos A, Castañeda-Ovando A, Cruz-Guerrero AE (2020) Valorization of whey using a biorefinery. Biofuels, Bioprod Biorefin 14(5):1010-1027. https://doi. org/10.1002/bbb.2100

2. Ariyanti D, Aini AP, Pinundi DS (2014) Optimization of ethanol production from whey through fed-batch fermentation using Kluyveromyces marxianus. Energy Proc 47:108-112

3. Christensen AD, Kádár Z, Oleskowicz-Popiel P, Thomsen MH (2011) Production of bioethanol from organic whey using Kluyveromyces marxianus. J Ind Microbiol Biotechnol 38(2):283-289

4. Ariyanti D, Hadiyanto $H$ (2013) Ethanol production from whey by Kluyveromyces marxianus in batch fermentation system: kinetics parameters estimation. Bull Chem React Eng Catal 7(3):179-184

5. Domingos JMB, Puccio S, Martinez GA, Amaral N, Reis MAM, Bandini S, Fava F, Bertin L (2018) Cheese whey integrated valorisation: production, concentration and exploitation of carboxylic acids for the production of polyhydroxyalkanoates by a fedbatch culture. Chem Eng J 336:47-53. https://doi.org/10.1016/j. cej.2017.11.024

6. Lopes ACA, Eda SH, Andrade RP, Amorim JC, Duarte WF (2019) New alcoholic fermented beverages-potentials and challenges. In: Fermented beverages. Elsevier, pp 577-603

7. Kargi F, Ozmıhcı S (2006) Utilization of cheese whey powder (CWP) for ethanol fermentations: effects of operating parameters. Enzyme Microb Technol 38(5):711-718. https://doi. org/10.1016/j.enzmictec.2005.11.006

8. Koushki M, Jafari M, Azizi M (2012) Comparison of ethanol production from cheese whey permeate by two yeast strains. J Food Sci Technol 49(5):614-619

9. Gabardo S, Rech R, Rosa CA, Ayub MAZ (2014) Dynamics of ethanol production from whey and whey permeate by immobilized strains of Kluyveromyces marxianus in batch and continuous bioreactors. Renew Energy 69:89-96

10. Oda Y, Nakamura K, Shinomiya N, Ohba K (2010) Ethanol fermentation of sugar beet thick juice diluted with crude cheese whey by the flex yeast Kluyveromyces marxianus KD-15. Biomass Bioenergy 34(8):1263-1266. https://doi.org/10.1016/j.biomb ioe.2010.03.014

11. Aktaş N, Boyacı IH, Mutlu M, Tanyolaç A (2006) Optimization of lactose utilization in deproteinated whey by Kluyveromyces marxianus using response surface methodology (RSM). Biores Technol 97(18):2252-2259. https://doi.org/10.1016/j.biort ech.2005.10.039

12. Mo W, Wang M, Zhan R, Yu Y, He Y, Lu H (2019) Kluyveromyces marxianus developing ethanol tolerance during adaptive evolution with significant improvements of multiple pathways. Biotechnol Biofuels 12(1):63. https://doi.org/10.1186/s1306 8-019-1393-z

13. Lukjanenko J, Kovtuna K, Scherbaka R, Vigants A (2014) Bioethanol and biomass production by Kluyveromyces marxianus during lactose fermentation at different salts and substrate concentrations. J Biotechnol 185:S122

14. Zoppellari F, Bardi L (2013) Production of bioethanol from effluents of the dairy industry by Kluyveromyces marxianus. New Biotechnol 30(6):607-613
15. TAM Consult (2008) Study on dairy investment opportunities in Ethiopia. SNV Netherlands Devlopment Organization

16. Yilma Z, Guernebleich E, Sebsibe A, Fombad R (2011) A review of the Ethiopian dairy sector. Addis Ababa, Ethiopia: FAO Sub Regional Office for Eastern Africa (FAO/SFE)

17. Minten B, Habte Y, Tamru S, Tesfaye A (2020) The transforming dairy sector in Ethiopia. PLoS ONE 15(8):e0237456

18. Patricia C (1995) Official methods of analysis of AOAC International, vol 2. Arlington, Va.: AOAC Intl. pv (loose-leaf). Association of Official Analytical Chemists, Washigton DC

19. Miller GL (1959) Use of dinitrosalicylic acid reagent for determination of reducing sugar. Anal Chem 31(3):426-428

20. Huang L, Zhang B, Gao B, Sun G (2011) Application of fishmeal wastewater as a potential low-cost medium for lipid production by Lipomyces starkeyi HL. Environ Technol 32(16):1975-1981. https://doi.org/10.1080/09593330.2011.562551

21. Zafar S, Owais M (2006) Ethanol production from crude whey by Kluyveromyces marxianus. Biochem Eng J 27(3):295-298

22. Ozmihci S, Kargi F (2007) Ethanol fermentation of cheese whey powder solution by repeated fed-batch operation. Enzyme Microb Technol 41(1):169-174. https://doi.org/10.1016/j.enzmi ctec.2006.12.016

23. Mohd Azhar SH, Abdulla R, Jambo SA, Marbawi H, Gansau JA, Mohd Faik AA, Rodrigues KF (2017) Yeasts in sustainable bioethanol production: a review. Biochem Biophys Rep 10:52-61. https ://doi.org/10.1016/j.bbrep.2017.03.003

24. Jin Y, Parashar A, Mason B, Bressler DC (2016) Simultaneous hydrolysis and co-fermentation of whey lactose with wheat for ethanol production. Biores Technol 221:616-624. https://doi. org/10.1016/j.biortech.2016.09.063

25. Beniwal A, Saini P, Kokkiligadda A, Vij S (2017) Physiological growth and galactose utilization by dairy yeast Kluyveromyces marxianus in mixed sugars and whey during fermentation. 3 Biotech 7(5):349. https://doi.org/10.1007/s13205-017-0985-1

26. Fonseca GG, de Carvalho NMB, Gombert AK (2013) Growth of the yeast Kluyveromyces marxianus CBS 6556 on different sugar combinations as sole carbon and energy source. Appl Microbiol Biotechnol 97(11):5055-5067. https://doi.org/10.1007/s0025 3-013-4748-6

27. Murari CS, Machado WRC, Schuina GL, Del Bianchi VL (2019) Optimization of bioethanol production from cheese whey using Kluyveromyces marxianus URM 7404. Biocatal Agric Biotechnol 20:101182. https://doi.org/10.1016/j.bcab.2019.101182

28. Sansonetti S, Curcio S, Calabrò V, lorio G (2009) Bio-ethanol production by fermentation of ricotta cheese whey as an effective alternative non-vegetable source. Biomass Bioenergy 33(12):1687-1692

29. Kourkoutas Y, Dimitropoulou S, Kanellaki M, Marchant R, Nigam P, Banat IM, Koutinas AA (2002) High-temperature alcoholic fermentation of whey using Kluyveromyces marxianus IMB3 yeast immobilized on delignified cellulosic material. Biores Technol 82(2):177-181. https://doi.org/10.1016/S0960-8524(01)00159-6

30. Banat I, Singh D, Marchant R (1996) The use of a thermotolerant fermentative Kluyveromyces marxianus IMB3 yeast strain for ethanol production. Acta Biotechnol 16(2-3):215-223

Publisher's Note Springer Nature remains neutral with regard to jurisdictional claims in published maps and institutional affiliations. 